\title{
Type 1 plasminogen activator inhibitor
}

\author{
三 室淳*
}

Jun MIMURO*

Key words: PAI-1, cDNA, fibrinolysis, PAI-1 binding protein

I. 緒 言

Fibrinolytic system (線溶系) は, plasminogen がその特異的な activator により活性 型の broad spectrum な serine protease であ る plasmin となり，血栓の fibrin を溶解する ことから名付けられている。線溶系はただ単に 血管内において血栓溶解に働くばかりでなく， 炎症, 組織破壊, 細胞の移動, 腫瘍細胞の転 移, 血管新生, など種々の生物反応において重 要な役割を果たしている $(\text { Fig. 1 })^{1,2)}$. 線溶系 の作動は tissue type plasminogen activator (tPA) と urokinase type plasminogen activator (uPA) によって plasminogen が活 性化されることで開始される。これら両 $\mathrm{PA}$ の活性は，それらの特異的 inhibitor である Type 1 plasminogen acitvator inhibitor (PAI -1), および cell receptor, cell matrix, cofactor 等により制御されている1). 特に PA と PAI-1 の balance により線溶開始活性が決ってくる ので, PAI-1 の細胞での産生の増減や, PAI1 分子自体の活性の変動は前述した生物反応に 大きく影響する ${ }^{1)}$. PAI-1 の生理学的重要性は 数々の臨床例からも確かめられている。例えば PAI-1 が減少するような病態では出血傾向が 認められ, 一方, 血栓症の患者において血中 PAI-1 の上昇を認める例がある。本論文では PAI-1 の生化学, 分子生物学的側面について
述べてゆく.

\section{PAI-1 の一次構造}

Human $^{3 \sim 5)}$, bovine ${ }^{6)}$, rat $^{7)}$, mouse ${ }^{8)}$ の PAI-1 cDNA が cloning されており，それらの cDNA sequence からアミノ酸配列が決定され ている. PAI-1 は signal peptide (23アミ)

\section{Fibrinolytic System}

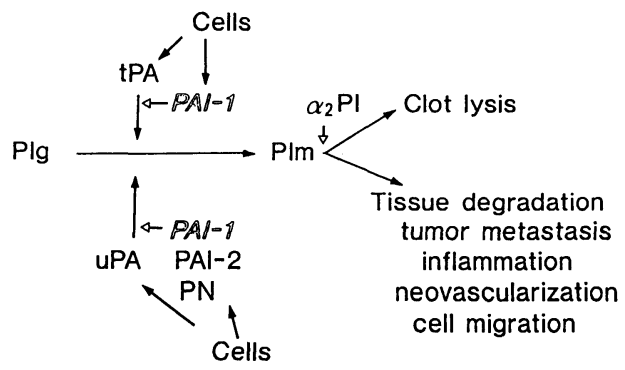

Fig. 1 線溶系の模式図 線溶系の開始は plasminogen (Plg) を tPA あるいは uPA が活性化することで行 われる. plasmin (Plm) は血栓溶解に働く ばかりでなく，組織破壊にも働く，PAI-1 は plasmin generation の段階で， $\alpha_{2}$ plasmin inhibitor $\left(\alpha_{2} \mathrm{PI}\right)$ は生じた plasmin を 抑制することにより線溶系を制御してい る.このように, 線溶系は SERPIN によ り 2 段階で制御されている.

* 自治医科大学医学部 血液研究所 止血血栓部門 講師〔 $\bar{\top}$ 329-04 栃木県河内郡南河内町薬師寺 3311-1〕; Division of Hemostasis and Thrombosis, Institute of Hematology, Jichi Medical School, Tochigi-ken 329 


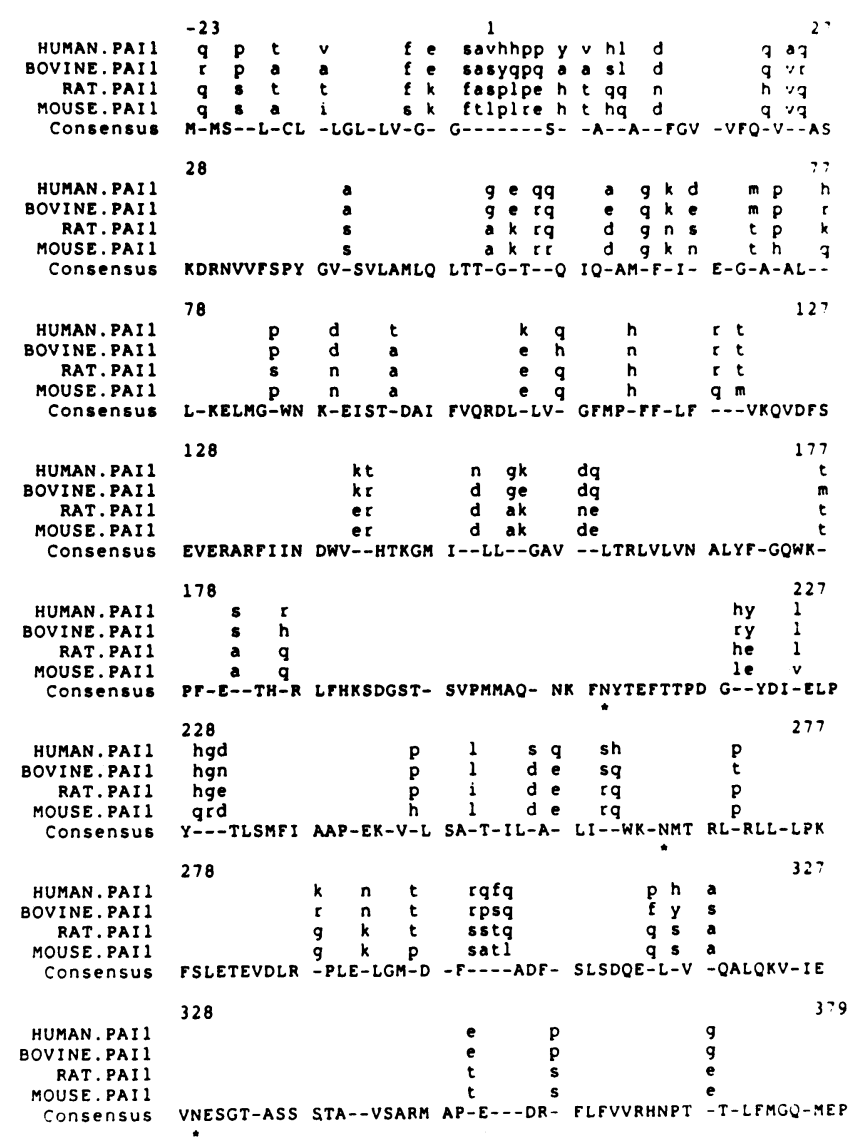

Fig. 2 各種 PAI-1 のアミノ酸配列の比較

Human, bovine, rat mouse PAI-1 のアミノ酸配列から得られた consensus sequence を示し てある. 保存されていないアミノ酸（non-polar↔polar, bacic↔acidic の変異）はそれぞれ のアミノ酸を示してある. $\mathrm{N}$ 末端アミノ酸は+1で示してある. signal peptide はー2 23 らー1 迄である. reactive center の $\operatorname{Arg}\left(\mathrm{P}_{1}\right)-\operatorname{Met}\left(\mathrm{P}_{1}^{\prime}\right)$ は (へ) で, また N-linked glycosylation site は $(*)$ で示してある.

酸）を含む 402 アミノ酸からなる polypeptide として産生されるが, 細胞内で processing を 受け，379アミノ酸からなる一本鎖の糖蛋白と なり分泌される ${ }^{1,4 \sim 6)}$. アミノ酸配列で特徵的な ものは, PAI-1 が cysteine 残基 (signal peptide に 1つあるが分泌される PAI-1 には無 (）を持たないことである ${ }^{3 \sim 7)}$.すなわち，蛋 白分子の安定化に関与する分子内 $\mathrm{S}-\mathrm{S}$ 結合が PAI-1 分子内には無いことになる.アミノ酸 配列からは，3つの potential $\mathrm{N}$-linked glycosylation sites があり ${ }^{3 \sim 7)}$, glycosidase に よる実験からは，そのいずれもが糖鎖を持って いると考えられる9. これらの glycosylation sites はいずれの PAI-1 分子においても同一の
部位にある．Rat PAI-1 はこの他にもう $1 つ$ glycosylation site があるがこれが糖鎖をもっ ているかは明かではない。これら PAI-1 分子 のアミノ酸配列の比較検討からは，PA と反応 する reactive center はいずれもが Arg-Met であり, reactive center 付近のアミノ酸配列 は類似性が高いことが分かる (Fig. 2)，その一 方で，N-末端付近は類似性が低い. PAI-1 は serine protease inhibitor (SERPIN) surerfamily に属し, $\alpha_{1}$-antitrypsin $ゃ$ antithrombin III と類似の構造を持つ ${ }^{344)}$. すなわち, reactive center は, $\mathrm{C}$ 末端付近の exposed loop 上にあり，PA との反応に際しては， reactive center の $\operatorname{Arg}\left(\mathrm{P}_{1}\right)$ と $\operatorname{Met}\left(\mathrm{P}_{1}^{\prime}\right)$ の間 
Table 1. Plasminogen activator (PA) と Plasminogen activator inhibitor (PAI) の反応定数 (Second-order rate constant ; $\mathrm{K}$ assoc)

\begin{tabular}{clrc}
\hline PA & \multicolumn{1}{c}{ PAI } & K assoc $\left(\mathrm{M}^{-1} \mathrm{~s}^{-1}\right)$ & Reference \\
\hline tPA, one chain & bovine PAI-1 & $3.7 \times 10^{7}$ & 41 \\
& Rat PAI-1 & $3.7 \times 10^{7}$ & 42 \\
& human PAI-1 & $7 \times 10^{6}$ & 43 \\
& PAI-2 & $9 \times 10^{2}$ & 44 \\
& Protease Nexin-1 & $1.5 \times 10^{3}$ & 45 \\
tPA, two chain & bovine PAI-1 & $1.5 \times 10^{8}$ & 41 \\
& plasma PAI-1 & $3 \times 10^{7}$ & 43 \\
& human PAI-1 & $1.5 \times 10^{7}$ & 44 \\
& PAI-2 & $2.5 \times 10^{5}$ & 45 \\
Urokinase, high & protease Nexin-1 & $3 \times 10^{4}$ & 41 \\
molecular weight & bovine PAI-1 & $1.6 \times 10^{8}$ & 42 \\
& Rat PAI-1 & $5 \times 10^{7}$ & 44 \\
& PAI-2 & $9 \times 10^{5}$ & 45 \\
\hline
\end{tabular}

にて解裂が起こり $\mathrm{P}_{1}$ の $\mathrm{Arg}$ 残基は PA の活性 serine 残基との間に covalent bond を作る。こ の反応は極めて速く, second order rate constant は tPA と PAI-1 の間で $10^{6-7} / \mathrm{M} / \mathrm{s}$ 以 上，UK と PAI-1 の間で $10^{7-8} / \mathrm{M} / \mathrm{s}$ 以上であ り, 他の PA inhibitor 活性を持つ蛋白 (PAI2, protease nexin-1) と比較し second order rate constant において 1000〜10000 以上の開 きが在る (Table 1)。このことからも，PAI-1 が tPA や uPA の生理的 inhibitor であること が分かる。

\section{PAI-1 の分子生物学}

前述のように， 4 種の PAI-1 cDNA が cloning されている ${ }^{3 \sim 8)}$.これら cDNA から推定さ れる mRNA は基本的には同様の構造をしてお り, 約 120〜140 bp の $5^{\prime}$-untranslated region, $12.06 \mathrm{bp}$ の coding region (23 アミノ酸からな る signal peptide を含む 402 アミノ酸を code する）そして約 $1.7 \mathrm{~kb}$ の $3^{\prime}$-untranslated region からなる. 3'-untranslated region には $\mathrm{AU}$ rich sequence が在る ${ }^{3 \sim 7)}$. AU rich sequence は ribonuclease $に$ sensitive ではな いかと考えられている3 7).ただし，ribonuclease $に$ sensitive な consensus sequence $と$ して知られている反復する AUUU sequence は bovine PAI-1 mRNA にのみ在る ${ }^{6)}$. cDNA
を probe としておこなった Northern blot か らは human cell においては $3.2 \mathrm{~kb} と 2.3$ $\mathrm{kb}^{3,5)}$, bovine cell において, $3 \mathrm{~kb}$ と $1.6 \mathrm{~kb}$ の 2 種類の $\mathrm{mRNA}^{10)}$ がみとめられている. human system では alternative polyadenylation, bovine system では ribonucease による 3 $\mathrm{kb}$ mRNA の AUUU sequence での分解と, それぞれ異なった機序が，2 種の mRNA の成 因と考えられている ${ }^{3 \sim 6,10)}$.

PAI-1 gene は第 7 染色体上 q 21.3-q 22 に あり ${ }^{5,11)}$, cystic fibrosis gene の近傍にある ${ }^{11)}$. PAI-1 の gene structure ${ }^{12,13)}$ と全 DNA sequence $^{13)}$ が決められている。これによると, PAI-1 gene は 9 exon と 8 intron からなり， promoter を含む $5^{\prime}$ flanking region は $6 \mathrm{~kb}$ 以 上ある.PAI-1 gene は制御が強くかかること が知られている. Transforming growth factor $\beta$, Tumor necrosis factor $\alpha$, Interleukin1 また endotoxin は血管内皮細胞で PAI-1 mRNA レベル10,14) および PAI-1 分子の産

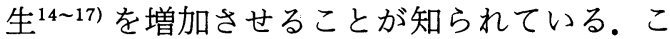
の他 steroid hormone は fibrosarcoma cell line ${ }^{18,19)}$ や hepatoma cell line ${ }^{20)}$ で PAI-1 の生 産を増加する。また, PAI-1 gene の promotor region の解析からは dexamethasone に 反応する sequence が決められている211. 


\section{PAI-1 の活性の制御}

PAI-1 の活性を制御するものは PAI-1 を失 活させるもの, 安定化させるもの, そして非活 性型の PAI-1 を活性化するものに大別される.

PAI-1 を失活させるものには，oxidant と protease が知られている. PAI-1 の active center は Arg-Met であり, $\mathrm{P}^{\prime}{ }_{1}$ の Met が oxidation を受け失活すると考えられてい る22). PAI-1 は SERPIN であり，その target protease である PA あるいは，その他の protease と反応し複合体を形成するに際しそ の活性を失う。その一方，ある protease は PAI-1 を bait region において限定分解する. 前者に属するものに PA, activated protein $\mathrm{C}^{23)}$ そして contact phase protease $\mathrm{e}^{24)}$ があり，後者 には thrombin ${ }^{25,26)} そ し て ~$ elastase $^{27)}$ がある。 activated protein $\mathrm{C}$ は PAI-1 を失活させ線溶 活性を上昇させると報告されてきた ${ }^{23,24)}$ 。この 反応は protease と protease inhibitor の反応 であり，複合体を形成した PAI-1， activated protein C ともに失活している.すなわち, activated protein C が PAI-1 を限定分解して PAI-1 を失活させるのではない。この反応は 極めて遅い反応であり，大過剩の activated protein C を投与したときにおこると考えられ $ろ^{11}$.

PAI-1 には少なくとも二つの型（活性型 PAI-1 および latent PAI-1) が存在することが 知られている ${ }^{1,28)}$ 。精製された活性型 PAI-1 は

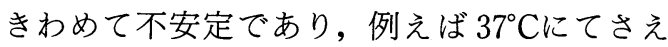
も容易に生物学的活性のない（すなわち PA と反応しない) latent PAI-1 へ変化する ${ }^{1,29)}$. latent PAI-1 は化学的安定性が高く，また蛋 白変性剤 (SDS，グアニジン塩酸，尿素) ${ }^{28)}$ Negatively-charged phospholipids ${ }^{30)}$ と反応さ せることにより，活性型 PAI-1 にすることが できる. PAI-1 は活性型 PAI-1 として細胞か ら産生され, PAI-1 分子に構造変化が起こり latent PAI-1 へと変化すると考えられる。こ れらのことは, PAI-1 が cysteine 残基をもた ず，分子内 S-S 架橋結合をもたない為，その 分子構造が環境により容易に変化することによ
るためと考えられる11. 以上のことからは，活 性型 PAI-1 を安定化する protein，あるいは latent PAI-1 を活性化する因子が存在すれば, それら因子は, PAI-1 分子の活性に影響する ことで線溶活性を制御し得る。活性型 PAI-1 を安定化する可能性がある protein (PAI-1 binding protein, PAI-1 結合蛋白) の存在は 種々の報告から示唆されている(後述 $)^{1)}$. そ の一方, latent PAI-1 を活性化する生理的因 子は末だ明かにされていず， latent PAI-1 の 活性化反応が生体内で起こるか否か，論議のあ るところである。

\section{PAI-1 Binding Protein}

\section{PAI-1 と Extracellular Matrix}

血管壁内皮細胞などより分泌され培養上清に 集積した PAI-1 は，そのほとんどが活性のな い latent PAI-1 であるが，培養血管壁内皮細 胞の細胞外基質 (Extracellular Matrix, ECM) に存在する PAI-1 は活性型である31)。また， 活性型 PAI-1 は ECM と結合することにより 安定化される ${ }^{32)}$.この ECM に存在する PAI-1 は tPA と反応し複合体をつくると $\mathrm{ECM} よ り$ 遊離する。このことは複合体の形成により PAI-1 の分子構造が大きく変わるためと考え られる。精製し isotope 標識した PAI-1 を $\mathrm{ECM}$ に加えると活性型 PAI-1 が特異的に ECM に結合する ${ }^{32)}$. 一方， latent PAI-1 の $\mathrm{ECM}$ への親和性は活性型 PAI-1 の $1 / 15$ 以下 である ${ }^{32)}$. 活性型 PAI-1 の ECM への結合は $\mathrm{kd}=60 \mathrm{nM}$ と強いが， $37^{\circ} \mathrm{C} て ゙$ 緩衝液中で incubationすると ECM に結合していた PAI-1 は 緩衝液中に放出される。これは，液相中の PAI-1 は latent PAI-1 に変化するため, 平衡 反応が PAI-1 を ECM から遊離する方向に傾 いているためと考えられる ${ }^{32)}$. isotope 標識 PAI-1 は ECM と結合することで安定化する. また ECM を種々の protease で処理すると PAI-1 結合能が失われる。これらの data から は, ECM 中に存在する何等かの蛋白が PAI-1 の結合と安定化に関与していると推測され $た^{32)}$.

\section{PAI-1 と血漿蛋白}


PAI-1 は血漿中には極低濃度 $(20 \mathrm{ng} / \mathrm{m} l)$ 存在する ${ }^{33)}$. PAI-1 はまた血小板に存在し血 小板の凝集反応にともない放出される ${ }^{34)}$. とこ ろで, 血漿 ${ }^{35)}$ あるいは血清36)を gel filtration column chromatography により分画すると， 活性型 PAI-1 は予想される分子量よりも高分 子領域に認められる。このことより, 活性型 PAI-1 は血液中では他の血漿蛋白と結合して いると考えられ，血漿中にも PAI-1 binding protein が存在するとされた ${ }^{35,36)}$.

\section{PAI-1 binding protein $の$ 精製}

近年，二つの group により ${ }^{37,38)} \mathrm{PAI}-1$ binding protein (PAI-1 BP) が血漿中より精製さ れた。結論的には, 両者ともに同じ protein を 精製した。精製された PAI-1 BP の $\mathrm{N}$ 末端ア ミノ酸解析と免疫学的検索により血漿 PAI-1 BP は，既知の血漿蛋白の一つである vitronectin と同じであることが明らかになっ た ${ }^{37,38)}$. vitronectin は ECM protein のひとつ であり，培養血管内皮細胞の ECM にも認めら れるので，ECM に存在する PAI-1 BP の一つ と考えられる ${ }^{37)}$.

\section{PAI-1 と vitronectin}

vitronectin は serum spreading factor とも 呼ばれ，また，補体系の S-protein と同一の蛋 白である。多くの細胞は vitronectin receptor を持っており，vitronectin は細胞の接着に重 要な役割を果たしている。 vitronectin に結合 した PAI-1 は， tPA また uPA と反応しこれ らを失活させる ${ }^{38,399}$. またその反応速度も変化 しない ${ }^{35)}$. PAI-1 と vitronectin の結合は可逆 的であり ${ }^{37,38)}$, vitronectin に結合していた PAI-1 は，PA と反応し PAI-1/PA 複合体を つくると vitronectin から遊離する ${ }^{38)}$. vitronectin を plastic microtiter plates に固相化さ せ, isotope 標識したPAI-1 を加えると, PAI -1 は plastic plates に結合する ${ }^{39)}$.この binding curve からは $\mathrm{kd}$ は $200 \mathrm{nM}$ とされる. PAI -1 の活性化の有無は PAI-1 の vitronectin に 対する結合に影響しないとする報告もあるが， 多くの報告 ${ }^{32,37,38,40)}$ からは, 活性型 PAI-1 が vitronectin に強く結合するのに対し, latent PAI-1 は極弱くのみ結合すると考えられる. vitronectin に結合した活性型 PAI-1 は遊離型 PAI-1 より安定である（活性半減期 $\mathrm{t} 1 / 2$ が約 2 倍に延長する) ${ }^{38)}$.また，vitronectin の latent PAI-1 に対する影響をみた報告 ${ }^{40)}$ から

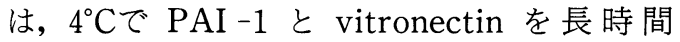
(5〜10日) incubationすると latent PAI-1 が 活性型に変化する。

vitronectin の PAI-1 binding site また PAI -1の vitronectin bgnding site はまだ明かにさ れていない. PAI-1 は vitronectin への細胞の 接着を阻害しないので36), vitronectin の $\mathrm{N}$ 末 端近くに存在する cell attachment site には PAI-1 は結合しないと考えられる。

Declerck ら ${ }^{13)}$ はPAI-1 は multimer おそら くは dimerの vitronectin とのみ結合するとし ているが，両者の結合は 1 対 1 とする報告もあ る. ligand blotting を用いた検討からは monomer の vitronectin も PAI-1 を結合しえる (Mimuro, Seiffert \& Loskutoff, 未発表 data).

\section{PAI-1 と vitronectin の結合の生理的意} 義

PAI-1 は血中に $20 \mathrm{ng} / \mathrm{m} l$ と低濃度で存在す るのに対し vitronectin は 200 400 $\mu \mathrm{g} / \mathrm{ml}$ と PAI-1 の約 10,000 倍の濃度で存在する. 血中 の vitronectin のすべてが PAI-1 を結合できる か否かは明かではないが，仮に血中の全 vitronectin が PAI-1 を結合しえるとすると， 血中の PAI-1 はほとんど vitronectin との複合 体として存在すると考えられる。 vitronectin は不安定な活性型 PAI-1 に対し安定化作用が あるが，PAI-1 の流血中からの clearance は 極めて速く (t $1 / 2=7 \mathrm{~min})^{1)}$ ，この安定化作用 が血液中で生理的意味があるか否かは明かでは ない。また， $4^{\circ} \mathrm{Cで}$ 起こる vitronectin による latent PAI-1 の活性化反応は極めて遅く, $37^{\circ} \mathrm{C}$ 生体内での生理的意義は少ないと考えら れる。むしろ，vitronectin は生体内では血中 ばかりでなく組織にも存在するので，PAI-1 を組織に局在化し組織内濃度を高めることで, 線溶系が関与する生物学的反応を制御している かも知れない。 


\section{文献}

1) Loskutoff DJ, Sawdey M, Mimuro J : Type 1 plasminogen activator inhibitor in "Progress in Hemostasis and Thrombosis", (Coller BS ed.) vol 9 : 1989, pp 87 115. WB Saunders, Philadelphia.

2) Dano K, Anderasen PA, Grondahl-Hanses J, Kristenses P, Nielsen LS, Skliver L: Plasminogen activators, tissue degradation and cancer. Adv Cancer Res 44 : 139 266, 1985.

3) Ny T, Sawdey M, Lawrence DA, Millan JL, Loskutoff DJ : Cloning and sequence of a cDNA coding for the human $\beta$-migrating endothlialcell-type plasminogen activator inhibitor. Proc. Natl. Acad. Sci. U.S.A. 83 : 6776 6780, 1986.

4) Pannekoek $H$, Veerman $H$, Lambers $H$, Diergaarde $\mathrm{P}$, Verweih $\mathrm{CL}$, van Zonneveld $\mathrm{AJ}$, van Mourik JA : Endothelial plasminogen activator inhibitor (PAI) : A new member of serpin gene family. EMBO J. 5 : 2539 2544, 1986.

5) Ginsburg D, Zeheb R, Yang AY, Raferrty UM, Andreasen PA, Nielsen L, Dano K, Lebo RV, Gelehrter TD: cDNA cloning of human plasminogen activator inhibitor from endothelial cells. J. Clin. Invest. 78 : 1673 1680, 1986.

6) Mimuro J, Sawdey M, Hattori M, Loskutoff DJ : cDNA for bovine type 1 plasminogen activator inhibitor. Nucl. Acid Res. 17 : 8872, 1989.

7) Zeheb R, Gelehrter TD : Cloning and sequencing of cDNA for the rat plasminogen activator inhibitor-1. Gene 73 : 45 468, 1988.

8) Prendergast G, Cole MD: Posttranscriptional regulation of cellular gene expression by the $\mathrm{c}^{-}$ myc oncogene. Mol Cell. Biol. 9 : 124 134, 1989.

9) Mimuro J, Loskutoff DJ : Characterization of the immature form of plasminogen activator inhibitor type 1 (PAI-1) present in cultured bovineaortic endothelial cells (BAEs). Fibrinolysis 2, (suppl 1) 120, 1988.

10) Sawdey M, Podor T, Loskutoff DJ : Regulation of type 1 plasminogen acitvator inhibitor gene expression in cultured bovine aortic endothelial cells. J. Bil. Chem. 264 : 10396 10401, 1989.

11) Klinger $K W$, Winquist $R$, Riccio $A$, Andreasen
PA, Sartorio R, Nielsen LS, Stuart, Stanislovitss P, Watkins P, Douglas R, Grzeschik KH, Alitalo K, Blasi F, Dano K: Plasminogen activator inhibitor type 1 gene is located at region q21.3-q22 of chromosome 7 and genetically linked with cystic fibrosis. Proct. Natl. Acad Rci. U.S.A.

12) Loskutoff DJ, Linders M, Keijer J, Veerman H, van Heerikhizen $\mathrm{H}$, Pannekoek $\mathrm{H}$ : Structure of the human plasminogen activator inhibitor 1 gene: Nonrandom distribution of introns, Biochemistry 26 : 3763 3768, 1987.

13) Bosma PJ, van den Berg E, Kooistra T, Siemieniak DR, Slightom JL: Human plasminogen activator inhibitor-1 gene. J Biol Chem 263 : 9129 9141, 1988.

14) Schleef RR, Bevilacque MP, Sawdey M, Gimbrone RA Jr, Loskutoff DJ : Cytokine activation of vascular endothelium: Effects on tissue plasmonogen activator and type 1 plasminogen activator inhibitor. J. Biol. Chem. 263 : 5797 $\sim 5803,1988$.

15) Bevilacqua MP, Schleef RR, Gimbrene MA Jr, Loskutoff $\mathrm{KJ}$ : Regulation of the fibrinolytic sys. tem of cultured fuman vascular endothelium by interleukin 1. J Clin Invest 78: 587 591, 1986.

16) Mimuro J, Loskutoff DJ : Effect of transforming growth factor $\beta$ (TGF $\beta$ ) on the fibrinolytic system of cultured bovine aortic endothelial cells (BAEs). Thromb Hemostas 58 : 1647, 1987.

17) Colucci M, Paramo JA, Collen D : Generation in plasma of a fast acting inhibitor of plasminogen acitivator in response to endotoxin stimulation : J Clin Invest 75 : 818 824, 1985.

18) Andreasen PA, Puke $C$, Riccio A, Kristensen $P$, Nielsen LS, Lund LR, Blasi F, Dano K: Plasminogen activator inhibitor type 1 biosynthesis and mRNA level are increased by dexamethasone in human fibrosarcoma cells. Mol Cell Biol 7 : 3021 3025, 1987.

19) Medcalf $R$, Van den Berg E, Schleuning W-S : Glucocorticoid modulated gene expression of tissue-and urinary type plasminogen activator and plasminogen activator inhibitor 1 and 2. J Cell Biol 106 : 971 978, 1978.

20) Loskutoff DJ, Roegner K, Erickson LA, Schleef 
RR, Huttenlocher A, Coleman PL, Gelehrter TD.: The dexamethasone-induced inhibitor of plasminogen activator in hepatoma cells is antigenically related to an inhibitor produced by bovine aortic endothelial cells. Thromb Haemostas 55 : 8 11, 1986.

21) van Zonneveld AJ, Currides S, Loskutoff DJ : Type 1 plasminogen activator inhibitor gene: Functional analysis and glucocorrticoid regulation of its promoter. Proc. Natl Acad Sci USA 85 : 5525 5529, 1988.

22) Lawrence DA, Loskutoff DJ : Inactivation of plasminogen activator inhibitor by oxidants. Biochemistry 25 : 6351 6355, 1986.

23) Sakata Y, Curriden SA, Lawrence DA, Griffin JH, Loskutoff DJ : Activated protein C stimulates the fibrinolytic activity of cultured endothelial cells and decreases antiactivaor acitivity. Proc Natl Acad Sci USA 82 : 1121 1125, 1985.

24) Berrittini M, Schleef RR, Espana F, Loskutoff DJ, Griffin JH : Interaction of type 1 plasminogen activator inhibitor with the enzymes of the contact activation system. J. Biol. Chem 264 : 11738 $\sim 11743,1989$.

25) de Fouw NJ, van Hinsgergh VWM, de Jong YF, Haverkate F, Bertina RM: The interaction of activated protein $\mathrm{C}$ and thrombin with the plasminogen activator inhibit released from endothelial cells, Thromb Haemost 57 : 176 182, 1987.

26) Knudsen BS, Hapel PC, Nachman RL: Plasminogen activator inhibitor is associated with the extracellular matrix of cultured bovine smooth muscle cells. J Clin Invest $80: 1082 \sim 1089$, 1987.

27) Levin EG, Santell L : Association of plasminogen activator inhibitor (PAI-1) with the growth substrutum and membrane of human dndothelial cells. J Cell Biol 105 : 2543 2549, 1987.

28) Hekman CM, Loskutoff DJ : Endothelial cells produce a latent inhibitor of plasminogen activators that can be activated by denaturants. J Biol Chem 260 : 11581 19

29) Hekman CM, Loskutoff DJ : Bovine Plasminogen activator inhibitor 1 : Specificity determinations and comparison of the active latent and guanidine-activated forms. Biocheminstry 27 : 2911 2918, 1988.

30) Lambers JWJ, Cammenga M, Konig B, Pannekoek H, van Mourik JA: Activation of human endothelial cell type plasminogen activator inhibitor (PAI-1) by negatively charged phospholipids. J Biol Chem 262 : 17492 17496, 1987.

31) Mimuro J, Schleef RR, Loskutoff DJ : Extracellular matrix of cultured bovine aortic endothlial cells contains functionally active type 1 plas minobgen activator inhibitor. Blood 70: 721 $\sim 728,1987$.

32) Mimuro J, Loskutoff DJ : Binding of type 1 plasminogen activator inhibitor to the extracellular matrix of cultured bovine endothelial cells. J Biol Chem 264 : 5058 5063, 1989.

33) Kruithof EKO, Tran-Thang C, Gudinchet A, Hauert J, Nicoloso G, Genton C, Welti H, Bachmann F: Fibrinolysis in pregnancy. Astudy of plasminogen activator inhibitors. Blood 69: 460 $\sim 466,1987$.

34) Erickson LA, Ginsberg MH, Loskutoff DJ : Detection and partial characterization of an inhibitor of plasmonogen acitvator in human platelets. J Clin Invest 74 : 1465 1472, 1984.

35) Wiman B, Lindahl T, Almquist A : Evidence for a discrete plasminogen activator inhibitor binding protein in plasma. Thromb Haemost 59 : 392 $\sim 395,1988$.

36) Erickson LA, Hekman CM, Loskutoff DJ : Denaturant-induced stimulation of the $\beta$-migrating plasminogen activator inhibitor in endothelial cells and serum. Blood 68 : 1298 1305, 1986.

37) Mimuro J, Loskutoff DJ : Purification of a protein from bovine plasma that binds to type 1 plasminogen activator inhibitor and prevents its interaction with extracellular matrix. J. Biol Chem 264 : 936 939, 1989.

38) Decklerck PJ, DeMol M, Alessi M, Baudner S, Plaques E, Preissner KT, Muller-Berghaus G, Collen D : Purification and characterization of a plasminogen activator inhibitor-1 from human plasma. J Biol Chem 263 : 15454 15461, 1988.

39) Salonen E-M, Vaheri A, Pollanen J, Stephens R, Andreasen P, Mayer M, Dane K, Bailit J, Rous- 
lahti $\mathrm{E}$ : Interaction of plasminogen activator inhibitor (PAI-1) with vitronectin. J Biol Chem 264 : 6339 6343, 1989.

40) Wun TC, Palmier MO, Siegel SM, Smith CE : Affinity purification of active plasminogen activator inhibitor-1 (PAI-1) using immobilized anhydrourokinase. J Biol Chem 264 : 7862 2868, 1989.

41) Hekman CM, Loskutoff DJ : Kinetic analysis of the interactions between plasminogen activator inhibitor 1 and both urokinase and tissue plasminogen activator. Arch Biochem. Biophys 262 : 199 210, 1988.

42) Coleman PL, Patel PD, Cwikel BH, Rafferty UM, Sznycer-Laszuk R, Gelehrter TD : Characterization of the dexamethasone-induced inhibitor of plasminogen activator in HTC hepatoma cells. J Biol Chem 261 : 4352 4357, 1986.

43) Roder M, Philips M, Suenson E, Thorsen S : The influence of fibrin formation and degradation on the kinetics of inhibition of tissue type plas minogen activator (tPA) by plasminogen activator inhibitor 1 (PAI-1). Fibrinolysis 2, (suppl 1) $96,1988$.

44) Kruithof EKO, Vassalli JD: Schleuning WD, Mattaliano RJ, Bachmann F: Purification and characterization of a plasminogen activator inhibitor from the histicytic lymphoma cell line $\mathrm{U}$ -937. J Biol Chem 261 : 11207 11213, 1986.

45) Scott RW, Bergman BL, Bajpai A, Hersh PT, Podriquez $\mathrm{H}$, Jones $\mathrm{BN}$, Barreda $\mathrm{C}$, Watts $\mathrm{S}$, Baker JB: Protease Nexin. Properties and a modified purification procedure. J Biol Chem 260 : 7029 7034, 1985.

46) Colucci M, Paramo JA, Collen D : Inhibition of one-chain and two-chain forms of human tissue -type plasminogen activator by the fast-acting inhibitor of plasminoge activator in vitro and in vivo. J Lab Clin Med 108 : 53 59, 1986. 